\title{
Self-care of elderly people with diabetes mellitus and the nurse-patient interpersonal relationship
}

\author{
Autocuidado de pessoas idosas com diabetes mellitus e a relação interpessoal enfermeiro-paciente \\ Autocuidado de personas ancianas con diabetes mellitus y la relación interpersonal enfermero-paciente
}

$\begin{array}{r}\hline \text { Gerlania Rodrigues Salviano Ferreira' } \\ \text { ORCID: 0000-0002-6956-9831 } \\ \text { Lia Raquel de Carvalho Viana' } \\ \text { ORCID: 0000-0002-4220-906X } \\ \text { Cláudia Jeane Lopes Pimenta' } \\ \text { ORCID: 0000-0002-1458-8226 } \\ \text { Cleane Rosa Ribeiro da Silva' } \\ \text { ORCID: 0000-0002-0475-2950 } \\ \text { Tatiana Ferreira da Costa"' } \\ \text { ORCID: 0000-0002-6448-4302 } \\ \text { Jacira dos Santos Oliveira' } \\ \text { ORCID: 0000-0002-3863-3917 } \\ \text { Kátia Neyla de Freitas Macedo Costa' } \\ \text { ORCID: 0000-0003-2054-6943 } \\ \hline\end{array}$

'Universidade Federal da Paraíba. João Pessoa, Paraíba, Brazil. "Universidade Federal de Pernambuco. Vitória de Santo Antão,

Pernambuco. Brazil.

How to cite this article: Ferreira GRS, Viana LRC, Pimenta CJL, Silva CRR, Costa TF, Oliveira JS, et al. Self-care of elderly people with diabetes mellitus and the nurse-patient interpersonal relationship. Rev Bras Enferm. 2022;75(1):e20201257. https://doi.org/10.1590/0034-7167-2020-1257

\section{Corresponding author:}

Gerlania Rodrigues Salviano Ferreira E-mail: gerlania.rodrigues@hotmail.com

EDITOR IN CHIEF: Antonio José de Almeida Filho ASSOCIATE EDITOR: Alexandre Balsanelli

Submission: $11-18-2020$

Approval: 03-24-2021

\section{ABSTRACT}

Objective: To analyze the self-care activities of elderly people with diabetes mellitus and its correlation with the nurse-patient interpersonal relationship. Methods: Cross-sectional quantitative study, with 144 elderly people followed up in Family Health Units, with data collected by the Diabetes Self-Care Activities Questionnaire and Interpersonal Relationship Questionnaire in Nursing Care, being analyzed by descriptive and inferential statistics. Results: There was a greater accomplishment of the activities Take insulin injections as recommended (6.74), Take diabetes medications as recommended (6.55) and Take the indicated number of diabetes pills (6.52). The interpersonal relationship showed moderate effectiveness (80.6\%). The correlation between self-care with diabetes and interpersonal relationships showed a positive and significant value in the dimension Specific feeding. Conclusion: The effectiveness of the interpersonal relationship in nursing care resulted in greater compliance with activities related to specific food.

Descriptors: Self Care; Interpersonal Relations; Diabetes Mellitus; Aged; Nursing.

\section{RESUMO}

Objetivo: Analisar as atividades de autocuidado de pessoas idosas com diabetes mellitus e sua correlação com a relação interpessoal enfermeiro-paciente. Métodos: Estudo quantitativo transversal, com 144 idosos acompanhados em Unidades de Saúde da Família, sendo os dados coletados pelo Questionário de Atividades de Autocuidado com o Diabetes e Questionário de Relação Interpessoal no Cuidado de Enfermagem, sendo analisados por estatística descritiva e inferencial. Resultados: Houve maior realização das atividades Tomar as injeções de insulina conforme recomendado $(6,74)$, Tomar os medicamentos do diabetes conforme recomendado $(6,55)$ e Tomar o número indicado de comprimidos do diabetes $(6,52)$. A relação interpessoal apresentou moderada efetividade (80,6\%). A correlação entre o autocuidado com o diabetes e o relacionamento interpessoal apresentou valor positivo e significante na dimensão Alimentação específica. Conclusões: A efetividade da relação interpessoal no cuidado de enfermagem resultou em maior cumprimento das atividades referentes à alimentação específica.

Descritores: Autocuidado; Relações Interpessoais; Diabetes Mellitus; Idoso; Enfermagem.

\section{RESUMEN}

Objetivo: Analizar las actividades de autocuidado de personas ancianas con diabetes mellitus y su correlación con la relación interpersonal enfermero-paciente. Métodos: Estudio cuantitativo transversal, con 144 ancianos acompañados en Unidades de Salud de la Familia, los dados recogidos por Encuesta de Actividades de Autocuidado con el Diabetes y Encuesta de Relación Interpersonal en el Cuidado de Enfermería, siendo analizados por estadística descriptiva y inferencial. Resultados: Hubo mayor realización de las actividades Tomar las inyecciones de insulina conforme recomendado $(6,74)$, Tomar los medicamentos de diabetes conforme recomendado $(6,55)$ y Tomar el número indicado de comprimidos de diabetes $(6,52)$. La relación interpersonal presentó moderada efectividad $(80,6 \%)$. La correlación entre el autocuidado con el diabetes y la relación interpersonal presentó valor positivo y significante en la dimensión Alimentación específica. Conclusiones: La efectividad de la relación interpersonal en el cuidado de enfermería resultó en mayor cumplimento de las actividades referentes a la alimentación específica.

Descriptores: Autocuidado; Relaciones Interpersonales; Diabetes Mellitus; Anciano; Enfermería. 


\section{INTRODUCTION}

Chronic non-communicable diseases are the main causes of death and health problems in the world, causing about 41 million deaths each year, which corresponds to approximately $71 \%$ of all deaths. Among these diseases, diabetes mellitus has stood out due to the increase in its incidence and prevalence ${ }^{(1)}$.

Estimates indicate that 463 million people live with diabetes in the world; of these, 111 million are elderly people over 65 years of age, which results in greater vulnerability to the appearance of complications, leading to impairments in functional capacity and autonomy, given that diabetes is the 11 th cause of disability worldwide ${ }^{(2-3)}$. Brazil occupies the fifth place in the world ranking of countries with the highest number of cases, with approximately 16.8 million people in this condition, which is associated with high economic and social costs for individuals, families and society ${ }^{(2)}$.

Diabetes when uncontrolled can lead, in the long run, to the appearance of several complications, such as renal failure, blindness, amputations of the limbs, infarction, cerebrovascular and peripheral vascular disease, which can compromise the well-being and quality of life of affected individuals. However, preventive measures can be taken to avoid or minimize the deleterious effects of the disease, with emphasis on performing self-care activities ${ }^{(2,4)}$.

Self-care is one of the essential aspects in the treatment of the elderly person with diabetes, given that its practice improves health status and reduces the chances of complications. It consists of maintaining a healthy diet, practice of physical activity, continuous use of prescription drugs, glycemic monitoring, foot care and periodic consultations and tests ${ }^{(4)}$. However, studies show that people with diabetes perform self-care activities related to drug treatment more ${ }^{(5-8)}$.

The adoption of healthy behaviors and lifestyles is extremely important to achieve success in the treatment of diabetes mellitus, however this reality can be perceived as a major challenge for the elderly person affected, configuring a difficulty in adapting to the disease, that can negatively interfere with your physical, psychological and emotional state ${ }^{(9)}$.

Thus, it is essential that these elderly people with diabetes mellitus are supported and understood in their subjectivity, very well informed about their health condition, motivated to deal with obstacles and adequately trained to fulfill their treatment plan, being essential in this process the continuous education and support from family and health professionals, especially nurses $^{(3)}$. It is worth emphasizing the importance of the professional to consider, when drawing up the care plan, the involvement of elderly people with diabetes in decision-making and to extend it to family members and/or caregivers, in order to assist in maintaining the new habits and behaviors acquired ${ }^{(10)}$.

For this, it is essential to build a bond and make the professionalpatient interpersonal relationship effective. The care relationships established between both are the basis of all nursing activity. The nurse is one of the professionals who work in Primary Health Care, starting to live longer with the elderly person with diabetes, which favors the development of a close and continuous relationship ${ }^{(11-12)}$.

The relationship between the nurse and the patient with diabetes must be based on trust, empathy, qualified listening, attention, respect, horizontal dialogue, understandable guidelines and individual care for needs, considering the way patients understand and experience the disease ${ }^{(11)}$. The effectiveness of the interpersonal relationship contribute to the formulation of strategies discussed and agreed upon with the patient, which have a greater chance of being completed in their daily routine ${ }^{(11)}$.

As evidence of this, a study carried out in Norway with 202 patients found that the nurse-patient interaction has a powerful influence on the individual's hope, self-transcendence and meaning of life, as well as on levels of anxiety and depression ${ }^{(14)}$. In this perspective, although interpersonal relationships are of great importance in nursing care, the discussion on this topic in the area of health is still incipient.

Nationally and internationally, most studies portray the interpersonal relationship through operational elements and subjectively in qualitative research ${ }^{(11,14-17)}$. There are few studies with a quantitative approach that make use of validated instruments with appropriate psychometric properties to measure the construct of interpersonal relationships ${ }^{(11)}$.

Given this context, it is relevant to assess the interpersonal relationship in nursing care and the self-care activities of elderly people with diabetes, which will help nursing professionals to understand the importance of the relationships established with the user, identifying the skills they need be developed and improved so that there is a better interaction between nurse and patient. This will culminate in assistance with greater safety and quality, thus favoring the user to build a profile that manages their own health.

\section{OBJECTIVE}

To analyze the self-care activities of elderly people with diabetes mellitus and its correlation with the nurse-patient interpersonal relationship.

\section{METHODS}

\section{Ethical aspects}

This study followed Resolution 466/2012 of the National Health Council, being approved by the Research Ethics Committee. In addition, the participants signed the Free and Informed Consent Form.

\section{Design, study location and period}

This is a cross-sectional study, with a quantitative approach and guided by the STROBE tool, having been carried out in the Family Health Units (FHU) in the city of João Pessoa, state of Paraíba (PB), Brazil, between the months of June and October 2019.

\section{Population and sample; inclusion and exclusion criteria}

The population was composed of all elderly users with diabetes mellitus seen at the USFs who had the nurse working for at least one year, corresponding to 10,647 individuals distributed in the five Health Districts (HD): I - 2,641; II - 1,919; III - 3,072; IV - 1,554; V - 1461.

The sample selection was carried out according to the allocation method proportional to the number of elderly people with diabetes treated by each DS, compared to the total number of elderly people served (Table 1). 
Table 1 - Distribution of elderly people attended by Health District according to the presence of diabetes, João Pessoa, Paraíba, Brazil, 2019

\begin{tabular}{cccc}
\hline District & $\begin{array}{c}\text { Elderly } \\
\text { assisted }\end{array}$ & $\begin{array}{c}\boldsymbol{p}_{\mathrm{h}} \text { - Percentage of } \\
\text { Diabetic } \\
\text { elderly } \\
\text { assisted }\end{array}$ & $\begin{array}{c}\text { diabetic elderly people } \\
\text { attended (in relation to } \\
\text { the total number of } \\
\text { elderly people attended) }\end{array}$ \\
\hline I & 12,571 & 2,641 & $p_{1}=5.4 \%$ \\
II & 9,366 & 1,919 & $p_{2}=3.9 \%$ \\
III & 13,122 & 3,072 & $p_{3}=6.3 \%$ \\
IV & 7,391 & 1,554 & $p_{4}=3.2 \%$ \\
V & 6,184 & 1,461 & $p_{5}=3.0 \%$ \\
Total & 48,634 & 10,647 & - \\
\hline
\end{tabular}

Thus, the sample size obtained was: DS I = 37; DS II = 27; DS III = 38; DS IV = 22; and DS V = 18. Therefore, the total was 142 users. In order to operationalize the data collection, a maximum number of two patients per unit was established, being necessary to reach an even number for the proportional division. Therefore, an interview was included in DS I $(n=38)$ and II $(n=28)$, which resulted in a sample of 144 participants.

The inclusion criteria defined were: being 60 years of age or older; have a medical diagnosis of type 2 diabetes; be accompanied at the FHU for at least one year; and be waiting for the nursing consultation. Individuals with type 1 diabetes were not included, as it is a disease that is frequently identified in childhood and adolescence, which requires adherence to self-care practices throughout life. Elderly people who did not communicate verbally and who did not have cognitive conditions to answer the questions were excluded, as assessed by the Mini Mental State Examination ${ }^{(18)}$.

\section{Study protocol}

The study data were collected through individual interviews, in which the elderly were approached in the waiting room of the health unit. A semi-structured instrument was used to obtain sociodemographic data and clinical conditions, containing the following variables: sex, age group, conjugality, education, religion, occupation, personal and family income, social security situation and people with whom you lived; the Diabetes Self-Care Activities Questionnaire (PAF); and the Interpersonal Relationship Questionnaire in Nursing Care (IRQNC).

The average number of self-care activities performed was obtained using the PAF, translated, adapted, and validated for Brazilian culture in $2010^{(14)}$. It has 15 items, distributed in seven dimensions: General food (two items), Specific food (three items), Physical activity (two items), Blood glucose monitoring (two items), Foot care (three items) and Use of medication (with three items, used according to the medication regimen). It also includes three other items for the assessment of smoking. Cronbach's alpha (a) ranged from 0.09 to 0.86 in the inter-item correlation. In the test-retest evaluation, the lowest correlation was for the item Eating sweets $(a=0.15)$; and the highest, for items on cigarette use $(a=1.00)$. The inter-rater correlations ranged between $\mathrm{a}=0.29$ and $\mathrm{a}=1.00^{(19)}$.

The interpersonal relationship was assessed by the IRQNC. It is an instrument built and validated in 2017, in Brazil, in which the patient analyzes their interpersonal relationship with the nurse. It is the only instrument designed for this function that considers a nursing theory as an epistemic foundation of support - the theoretical framework used was the Interpersonal System of the Interacting Open Systems Model, by Imogene King ${ }^{(11)}$.

\section{Analysis of results and statistics}

The collected data was transferred to Microsoft Office Excel ${ }^{\circ}$; and, later, statistical analyzes were performed using the Statistical Package for the Social Sciences program (version 22.0). Data analysis was performed using descriptive and inferential statistics. The dependent variable included in the study was "self-care for diabetes", and the independent variable was "the interpersonal relationship in nursing care".

The PAF assesses the performance of a certain behavior for seven days a week, so the scores for each item can vary from 0 to 7 , and higher scores indicate better results. The items in the Specific food dimension should be inverted, where $7=0,6=1,5=2,4=3,3=4,2$ $=5,1=6,0=7$ and vice versa, as suggested in the revised SDSCA ${ }^{(19)}$.

The QRIC has 31 items with a Cronbach's alpha of 0.90 and a McDonald's omega of 0.92 . The first 20 questions can be answered as "never", "sometimes", "the vast majority of times" and "always", scored on a Likert scale from 1 to 4 . Questions 21 to 29 can be answered as "Never", "sometimes" and "always", scored from 1 to 3. Finally, questions 30 and 31 are single answer questions ${ }^{(11)}$.

The analysis is performed according to an estimated theta parameter value $(\theta)$ for the respondents' performance. As this is a complex calculation carried out with the help of free $R$ software, an electronic address is available for this purpose. The value obtained from the theta parameter $(\theta)$ suggests the level of effectiveness of the interpersonal relationship in nursing care: less than 30, very low effectiveness; 30 to 39, low effectiveness; 40 to 49 , moderate effectiveness; 50 to 59 , high effectiveness; and greater than or equal to 60 , very high effectiveness ${ }^{(11)}$.

The verification of the normality of the numerical data was performed using the Kolmogorov Smirnov test. The Spearman correlation coefficient was used to correlate the scales, the strength of association between the variables being quantified by the values between 1 and -1 , in which, the closer the correlation magnitude is to 1 , the less dispersion there is in the relationship, and consequently, the greater the strength ${ }^{(20)}$. Thus, the interpretation of the results was based on the following classification: correlation of low magnitude, less than 0.4 ; of moderate magnitude, equal to or greater than 0.4 ; and of a strong magnitude equal to or greater than $0.5^{(21)}$. The level of significance used for the statistical analyzes was $5 \%(p<0.05)$.

\section{RESULTS}

In this study, there was a higher prevalence of females (66.7\%), aged between 65 and 69 years (34\%), married or living in a stable relationship (54.9\%), aged 9 to 12 years study (33.3\%), practitioners of the Catholic religion (63.9\%), without occupation (80.6\%), personal and family income between one and three minimum wages $^{\prime}(88.2 \%$ and $88.9 \%$, respectively), retired (75\%) and living only with the spouse $(25.0 \%)$.

Regarding self-care activities with diabetes, higher adherence averages were observed in the items: Take insulin injections as recommended (6.74), Take diabetes medications as recommended 
(6.55) and Take the indicated number of diabetes pills (6.52). In contrast, the activities that showed the least adherence were: Eating sweets (6.01), Assessing blood sugar the recommended number of times (2.86) and Performing specific physical activities (1.53) (Table 2). Regarding self-care activities related to smoking, it was noticed that the majority of the elderly reported not smoking in the last seven days (91.7\%) or never having smoked $(52.1 \%)$.

Table 2 - Evaluation of self-care activities with diabetes in the elderly, João Pessoa, Paraíba, Brazil, 2019 ( $\mathrm{N}=144)$

\begin{tabular}{lc}
\hline Self-care activities & $\begin{array}{c}\text { Average adherence } \\
\text { (Standard deviation) }\end{array}$ \\
\hline Eating habits & $4.62(2.01)$ \\
$\quad$ Follow a healthy diet & $4.89(2.04)$ \\
Follow food guidelines & $4.15(2.20)$ \\
Specific eating & $4.69(1.33)$ \\
Eat five or more servings of fruits and/or vegetables & $4.77(2.24)$ \\
Eating red meat and/or whole milk products & $3.31(2.24)$ \\
Eating sweets & $6.01(1.74)$ \\
Physical activity & $2.58(1.89)$ \\
Perform physical activities for at least 30 minutes & $3.63(2.72)$ \\
Perform specific physical activities (walking, swimming, etc.) & $1.53(2.18)$ \\
Blood glucose monitoring & $3.13(2.69)$ \\
Assess blood sugar & $3.40(2.76)$ \\
Assess blood sugar the recommended number of times & $2.86(2.89)$ \\
Foot care & $4.61(2.49)$ \\
Examine their feet & $4.58(2.93)$ \\
Examine inside shoes before putting them on & $4.72(2.95)$ \\
Dry the spaces between your toes after washing them & $4.53(2.97)$ \\
Medication & $6.81(0.48)$ \\
Take diabetes medications as recommended & $6.55(1.39)$ \\
Take insulin injections as recommended & $6.74(0.74)$ \\
Take the indicated number of diabetes pills & $6.52(1.40)$ \\
\hline
\end{tabular}

\section{DISCUSSION}

The investigated elderly people showed a higher average in self-care activities related to medication practice, which could be due to the health environment in which they are inserted, considering that, even in Primary Care, in many places there is still a professional activity based on in the biomedical model, focusing on drug treatment and its effectiveness in maintaining adequate glycemic levels ${ }^{(8)}$.

Associated with this, the health culture established in the country also reinforces the idea that the use of medications is more effective than the adoption of preventive measures, as they have a faster and more noticeable effect in the control of diabetes, favoring a better accomplishment of these activities by patients ${ }^{(22)}$.

The lowest averages of self-care activities were found between eating sweets, practicing physical activity and monitoring blood glucose. Diabetes is a disease that requires comprehensive care, since adequate glycemic control is only achieved with the adoption of pharmacological and non-pharmacological measures ${ }^{(9)}$. However, the change in lifestyle represents the biggest challenge for most elderly people.

Evidencing this fact, a study carried out with elderly people who had exclusive access to the public health service in the municipality of Sobral, in the state of Ceará, showed that the participants understood the need to maintain healthy habits, with the adoption of a balanced diet and regular practice of physical activ-

The assessment of interpersonal relationships in nursing care for the elderly with diabetes showed moderate effectiveness $(80.6 \%)$, with an average of 46.11 and standard deviation of 3.84 , followed by discharge (18.1\%) and low (1.4\%). The correlation between the dimensions of the DSMQ and the QRIC showed a positive and significant value $(p<0.05)$ with the specific diet, showing that the greater the effectiveness in the interpersonal relationship between the nurse and the elderly person with diabetes, the higher is adherence to specific food. In addition, it is worth noting that, although the $p$ value was not significant ( $p>0.05)$, the greatest correlation was found between the QRIC and blood glucose monitoring activity (Table 3 ).

Table 3 - Correlation between the dimensions of self-care with diabetes and interpersonal relationships in nursing care for the elderly, João Pessoa, Paraíba, Brazil, 2019 ( $\mathrm{N}=144)$

\begin{tabular}{lcc}
\hline \multirow{2}{*}{ Dimensions of self-care } & \multicolumn{2}{c}{ IRQNC } \\
& $\mathbf{r}$ & $\boldsymbol{p}$ value* \\
\hline Eating habits & 0.001 & 0.992 \\
Specific eating & 0.181 & 0.029 \\
Physical activity & 0.164 & 0.050 \\
Blood glucose monitoring & 0.238 & 0.168 \\
Take care of feet & 0.066 & 0.431 \\
Medication & 0.196 & 0.395 \\
\hline *Spearman's correlation test;IRQNC-Interpersonal Relationship Questionnaire in Nursing Care.
\end{tabular}

'The minimum salary at the time of data collection was $\mathrm{R} \$ 1,045.00$. ity, however many individuals were resistant to this change, as it significantly interferes with their individual and family routine ${ }^{(12)}$.

In this sense, maintaining a healthy lifestyle requires joint efforts and the co-responsibility of professionals (especially nurses), users and family members in the management of diabetes selfcare, which can reduce the risk of complications, prevent health problems and promote a better quality of life $e^{(9,23)}$.

The low score in the activity of assessing blood sugar the recommended number of times could be related to individual factors of the elderly person and/or to problems in the organization of Primary Care, such as a low level of education to understand the importance of its performance and how to perform the technique properly, the pain resulting from this procedure, the presence of cognitive or functional impairments, the reduced economic power to acquire the materials, the beliefs and limiting cultural aspects, the difficulties in accessing health services, the failure in the supply of insulin by the government, among others ${ }^{(22,24)}$.

Regarding smoking, most participants reported never having smoked or having consumed their last cigarette for more than two years, which represents something positive for self-care. This is because smoking is one of the main risk factors for the development of diabetes and cardiovascular diseases, being associated with a high mortality rate ${ }^{(25-26)}$. Therefore, smoking cessation is an essential measure in the treatment of diabetes, given that smoking favors increased insulin resistance and cardiometabolic risk ${ }^{(27)}$. 
A systematic review with meta-analysis carried out with more than 1 million people identified that individuals who have diabetes and are smokers were about $50 \%$ more likely to die prematurely due to cardiovascular events, when compared to non-smokers ${ }^{(25)}$. Therefore, it is relevant to investigate the presence of smoking in elderly people with diabetes and encourage them to quit smoking, providing guidance on the benefits that this will bring to their health and quality of life ${ }^{(2)}$.

With regard to the assessment of interpersonal relationships in nursing care for the elderly with diabetes, moderate effectiveness was evidenced, suggesting that nurses have interpersonal skills that promote a satisfactory interaction with the user, but that still need to be improved to reach levels highest effectiveness.

Along this line, a systematic review carried out in Belgium describes that dignity and respect are fundamental values to be achieved for an effective interpersonal relationship in nursing care and cites five elements that should support these values: elements related to the nurse's behavior and attitude, person-centered care, patient participation, communication and situational aspects ${ }^{(28)}$.

During the performance of their activities, the nurse must develop skills that serve as facilitators in the interpersonal relationship process, in the establishment of bonds with the patients and the health team. In turn, such skills, which need to be trained and improved daily, consist of self-knowledge, verbal and non-verbal communication, knowing how to deal with differences between people and the act of putting oneself in the other's shoes ${ }^{(29)}$.

As a confirmation of this, in Paraná, a study that carried out home interventions with elderly people over a period of four months found that these actions made by nurses enabled the formation of bonds, being permeated by active listening and welcoming, as well as the definition of goals together with the patient, assessing their real health needs. In their reports, the elderly also expressed feelings of trust, affection, familiarity and attention to the team, for feeling welcomed and respected ${ }^{(30)}$.

Comprehensive care is something that subsidizes nursing care and is consolidated through embracement and bonding. The construction of the professional-user bond provides for closer relationships, allowing openness to humanized, sensitive and supportive care ${ }^{(13)}$.

The interpersonal relationship is an extremely complex and intrinsic construct to nursing care, which requires individual skills of the communicator and the receiver, through tuning and training. However, it is clear that care is often focused on the biomedical model, which prioritizes the disease, procedures and treatments more than the observation of the subject and the relationships that can be built between those who care and those who are care ${ }^{(13)}$. In this perspective, authors emphasize that, to reinforce the importance of patient-nurse interpersonal relationships, it is essential to reflect on the ideas of theorists such as Imogene King and Hildegard Peplau, who portray the transforming power of nursing relationships ${ }^{(11)}$.

A positive and significant correlation was identified between the interpersonal relationship and a dimension of self-care activities, showing that the greater the effectiveness in the interpersonal relationship between the nurse and the elderly person with diabetes, the higher the score for the specific feeding activity.

Corroborating these findings, a longitudinal study carried out in Ceará found that the effective interpersonal relationship of nurses led users with diabetes to desirable behaviors, such as the use of a sweetener, accomplishment of physical exercises, adherence to medication therapy and food control ${ }^{(31)}$. In Australia, authors found that effective actions taken by nurses reduced glycated hemoglobin levels in users with decompensated diabetes ${ }^{(32)}$.

The change in the individual's food routine represents one of the main elements for the effectiveness of the treatment of diabetes mellitus, however the change in habits represents one of the greatest challenges for both the patient and the nurse, due to the complexity that involves eating behavior. Compliance with the diet plan is influenced by several factors, such as sociocultural, economic values, motivation, family support, knowledge about the disease and monitoring of patients by professionals in the Basic Health Units ${ }^{(22)}$.

It is worth mentioning the fact that the greatest correlation was evidenced between the interpersonal relationship and the Blood glucose monitoring dimension, although it did not present statistical significance. Adherence to blood glucose monitoring can be influenced by individual factors of the elderly person and/or problems in the organization of Primary Care, such as a low level of education to understand the importance of its performance and how to perform the technique properly, the resulting pain of this procedure, the presence of cognitive or functional impairments, the reduced economic power to acquire the materials, the beliefs and the limiting cultural aspects, the difficulties in accessing health services, the failure in the supply of insulin by the public power, among others $(4,9,22)$.

In this context, the nurse, in his interpersonal relationships with the user, must carry out individualized and comprehensive care, through a horizontal dialogue - without impositions, inattention and infelicity -, knowing in depth the aspects that hinder the compliance with the therapeutic plan, discussing priorities, monitoring the performance of self-care activities, motivating participation and stimulating effort in handling your treatment ${ }^{(31)}$.

The role of nurses in monitoring elderly people with diabetes should be centered on health education, through interventions in nursing consultations, in the waiting room, in social groups, in home visits, in telephone follow-up and in other strategies that can help in the guidance and empowerment of these users, inducing healthy lifestyle habits ${ }^{(12-13,30)}$.

Thus, with the result of the present study, it is possible to infer that the nurse's effective interpersonal relationship emerges as a potential strategy for carrying out self-care activities, especially those related to physical activity and healthy eating habits. Confirming this finding, a randomized study carried out in Primary Care proved that, when the goals are jointly established between nurses and users, covering the specificities of each individual and being effectively monitored, this favors the formation of bonds and trust in the professional, which results in better compliance with self-care activities, decreased glycemic levels, stress related to the disease and complications ${ }^{(33)}$.

Although the assistance provided by nurses in Primary Care favors the fulfillment of self-care activities by the elderly person with diabetes, it is noted that this professional needs to improve the action strategies for these users. A study carried out in the Netherlands with nurses specialized in diabetes and behavioral changes found that, in more than half of the consultations, no 
actions were taken to encourage changes in habits, much less actions to overcome the barriers imposed by the disease ${ }^{(29)}$.

There are many barriers that compromise the interpersonal relationship with the user. Thus, a study carried out with nurses from health units in Minas Gerais pointed out the structural problems in the health system as well as the deficient academic training and based on the hospital biomedical model as obstacles to the effective care of patients with diabetes ${ }^{(22)}$.

A new barrier presented by these professionals is the change in the validity of the medical prescription, which has gone from four to six months since $2016^{(34)}$, which has contributed to a greater delay in the user's return to the health unit, compromising the monitoring and weakening the nurse-patient interpersonal relationship. In this context, it is noted that there is a need for reassessment and restructuring of the health system and practices. Nurses involved in the care process must become aware of their responsibility towards the elderly with chronic illness, assuming a more active posture and developing actions in accordance with SUS principles and guidelines.

Thus, the constant training of these professionals is essential, not only in technical-scientific knowledge (knowing-how), but in knowing how to relate (how to behave), so that it is possible to develop effective interpersonal relationships with members. of the team, with the user and their family, which favors the quality of care ${ }^{(11,30)}$. In addition, studies emphasize that nurses use theoretical frameworks to support their practice, contemplating the different dimensions of care, as their use increases the bond with the user and their trust in the professional, which provides more effective and effective ${ }^{(11,32)}$.

\section{Study limitations}

The use of the transversal method limited the study results, as it does not allow the establishment of the cause-and-effect relationship between the dimensions of self-care and the level of effectiveness of the interpersonal relationship. In addition, the absence of studies with the IRQNC and the lack of quantitative research limited the discussion of the results. However, the incipient number of research emphasizing the originality of the theme, emphasizing a field of nursing science that needs further study.

\section{Contributions to the field of nursing, health, or public policy}

The study can contribute to the opening of spaces for discussion about the daily relationships established between nurse and user, in order to list factors that can be worked to effectively and efficiently intervene in the care of elderly people with diabetes mellitus. It also provides subsidies for the elaboration of public policies, health management and strategies that aim to improve the attendance of the elderly person with diabetes in the FHUs and to continuously train the professionals of these services. Finally, it bases the reflection on the academic education of the nurse, since it is necessary to develop and improve the skills for an effective interpersonal relationship since graduation, covering the theoretical, practical and research dimensions.

\section{CONCLUSIONS}

The results of the present study showed that elderly people with diabetes had higher averages in self-care activities in the items related to Taking insulin injections as recommended; Take diabetes medications as recommended; and Take the indicated number of diabetes pills. On the other hand, the activities that showed lower averages were: Eating sweets; Assess blood sugar the recommended number of times; and Perform specific physical activities (walking, swimming, etc.).

There was founded a moderate effectiveness of the interpersonal relationship in nursing care. The correlation between the two scales was significant in two dimensions of the DSMQ, showing that the effectiveness of the interpersonal relationship led to a greater fulfillment of activities related to specific food.

The effective interpersonal relationship represented an extremely important tool in the nursing care, emerging as a potential strategy for carrying out self-care activities for the elderly with diabetes. Given these findings, it is necessary to carry out in different regions, populations and contexts, in order to support theresults and provide in the advance in nursing science.

\section{SUPPLEMENTARY DOCUMENT}

The research is result of the dissertation "Autocuidado de pessoas idosas com Diabetes Mellitus e a relação interpessoal enfermeiro-paciente", Located in the link repository: https:// repositorio.ufpb.br/jspui/handle/123456789/18637.

\section{FUNDING}

This study was funded by the Coordination for the Improvement of Higher Education Personnel - Brazil (CAPES) - Financing Code 001.

\section{REFERENCES}

1. Organização Pan-Americana de Saúde (OPAS). Dez ameaças à saúde que a OMS combaterá em 2019 [Internet]. 2019 [cited 2019 Nov 08]. Available from: https://www.paho.org/bra/index.php?option=com_content\&view=article\&id=5848:dez-ameacas-a-saude-que-a-omscombatera-em-2019\&Itemid=875

2. International Diabetes Federation (IDF). IDF Diabetes Atlas Ninth edition [Internet]. 2019[cited 2019 Nov 11]. Available from: https://www. diabetesatlas.org/upload/resources/2019/IDF_Atlas_9th_Edition_2019.pdf

3. Eid LP, Leopoldino SAD, Oller GASAO, Pompeo DA, Martins MA, Gueroni LPB. Factors related to self-care activities of patients with type 2 diabetes mellitus. Esc Anna Nery [Internet]. 2018[cited 2019 Nov 13];22(4):e20180046. Available from: https://www.scielo.br/pdf/ean/ v22n4/1414-8145-ean-22-03-e20180046.pdf 
4. American Diabetes Association (ADA). Classification and Diagnosis of Diabetes: Standards of Medical Care in Diabetes - 2019. Diabetes Care. 2019;42(Suppl 1):S13-S28. https://doi.org/10.2337/dc19-S002

5. Santos SD, Rocha MR, Moura IH, Paiva RG, Amorim TRS, Rocha AESH, et al. Self-care activities in people with type 2 diabetes mellitus. Rev Enferm UFPE [Internet]. 2019[cited 2020 Jan 30];13:e241793. Available from: https://periodicos.ufpe.br/revistas/revistaenfermagem/article/ view/241793/33599

6. Trevizani FA, Doreto DT, Lima GS, Marques S. Self-care activities, sociodemographic variables, treatment and depressive symptoms among older adults with Diabetes Mellitus. Rev Bras Enferm. 2019;72(Suppl 2):22-9. https://doi.org/10.1590/0034-7167-2017-0579

7. Costa Neto JD, Santos-de-Araújo AD, Santana TCFS, Rêgo AS, Ferreira PR, Bassi D. Adesão dos pacientes de diabetes mellitus às atividades de autocuidado. Rev Investig Bioméd [Internet]. 2018[cited 2020 Feb 02];10(2):132-41. Available from: http://www.ceuma.br/portalderevistas/ index.php/RIB/article/download/269/pdf

8. Coelho ACM, Boas LCGV, Gomides DS, Foss-Freitas MC, Pace AE. Self-care activities and their relationship to metabolic and clinical control of people with diabetes mellitus. Texto Contexto Enferm [Internet]. 2015[cited 2020 Feb 01];24(3):697-705. Available from: https://www.scielo.br/ pdf/tce/v24n3/0104-0707-tce-2015000660014.pdf

9. Vicente MC, Silva CRR, Pimenta CJL, Frazão MCLO, Costa TF, Costa KNFM. Resilience and self-care of elderly people with diabetes mellitus. Rev Rene [Internet]. 2019[cited 2019 Nov 30];20:e33947. Available from: http://periodicos.ufc.br/rene/article/view/33947/pdf_1

10. Gobert A, Vasques ACJ, Faria ACRA, Lottenberg AMP, Joaquim AG, Viana AGD, et al. Diretrizes da Sociedade Brasileira de Diabetes $2019-2020$ [Internet]. 2019[cited 2020 Feb 02]. São Paulo: Editora Clannad. Available from: https://www.diabetes.org.br/profissionais/images/DIRETRIZESCOMPLETA-2019-2020.pdf

11. Borges JWP, Moreira TMM, Andrade DF. Nursing Care Interpersonal Relationship Questionnaire: elaboration and validation. Rev Latino-Am Enfermagem [Internet]. 2017[cited 2019 Nov 21];25:e2962. Available from: https://www.scielo.br/pdf/rlae/v25/0104-1169-rlae-25-e2962.pdf

12. Lima AF, Moreira ACA, Silva MJ, Monteiro PAA, Teixeira PG. The perception of the elderly with diabetes on their disease and the nursing care. Ciênc Cuid Saúde [Internet]. 2016[cited 2019 Nov 13];15(3):522-9. Available from: http://www.periodicos.uem.br/ojs/index.php/ CiencCuidSaude/article/view/30884/18072

13. Nickelsen NCM. The infrastructure of telecare: implications for nursing tasks and the nurse-doctor relationship. Sociol Health Illn [Internet]. 2019[cited 2019 Nov 11];41(1):67-80. Available from: https://onlinelibrary.wiley.com/doi/abs/10.1111/1467-9566.12781

14. Haugan G, Moksnes UK, Løhre A. Intrapersonal self-transcendence, meaning-in-life and nurse-patient interaction: powerful assets for quality of life in cognitively intact nursing-home patients. Scand J Caring Sci [Internet]. 2016[cited 2019 Nov 29];30(4):790-801. Available from: https:// pubmed.ncbi.nlm.nih.gov/26917325/

15. Borges JWP, Moreira TMM, Silva DB, Loureiro AMO, Meneses AVB. Adult nursing-patient relationship: integrative review oriented by the king interpersonal system. Rev Enferm UFPE[Internet]. 2017[cited 2019 Sep 11];11(4):1769-78. Available from: https://periodicos.ufpe.br/revistas/ revistaenfermagem/article/view/15249/18036

16. Branco LASC, Maia NMFS, Lima LAA. A construção do vínculo enfermeiro-cliente pelo diálogo no ambiente hospitalar. Rev Enferm UFPI [Internet]. 2016[cited 2019 Sep 19];5(3):30-5. Available from: https://revistas.ufpi.br/index.php/reufpi/article/view/5436/pdf

17. Lindner R. Gerontopsychosomatic consultation/liaison service in inpatient acute geriatrics : effects of trust and support on patient-nurse interaction. Z Gerontol Geriat [Internet]. 2018[cited 2019 Nov 08];51:404-10. Available from: https://link.springer.com/article/10.1007\%2 Fs00391-018-1393-9

18. Folstein M, Folstein S, Mchugh P. "Mini-mental state": a practical method for grading the cognitive state of patients for the clinician. J Psychiatr Res [Internet]. 1975[cited 2019 Sep 09];12(3):189-98. Available from: https://www.sciencedirect.com/science/article/abs/ pii/0022395675900266?via\%3Dihub

19. Michels MJ, Coral MHC, Sakae TM, Damas TB, Furlanetto LM. Questionário de Atividades de Autocuidado com o Diabetes: tradução, adaptação e avaliação das propriedades psicométricas. Arq Bras Endocrinol [Internet]. 2010[cited 2019 Dec 23];54(7):644-51. Available from: https://www. scielo.br/pdf/abem/v54n7/09.pdf

20. Glantz SA. Princípios de bioestatística. 7. ed. Porto Alegre: AMGH, 2014.

21. Hulley SB, Cummings SR, Browner WS, Grady DG, Newman TB. Delineando a pesquisa clínica. 4. ed. Porto Alegre: Artmend; 2015.

22. Gama CAP, Guimarães DA, Rocha GNG. Diabetes Mellitus e atenção primária: percepção dos profissionais sobre os problemas relacionados ao cuidado oferecido às pessoas com diabetes. Pesqui Prát Psicossoc[Internet]. 2017[cited 2019 Nov 11];12(3):1-16. Available from: http://pepsic. bvsalud.org/pdf/ppp/v12n3/13.pdf

23. Shu L, Shen XM, Li C, Zhang XY, Zheng PF. Dietary patterns are associated with type 2 diabetes mellitus among middle-aged adults in Zhejiang Province, China. Nutr J [Internet]. 2017[cited 2019 Dec 25];16:81. Available from: https://nutritionj.biomedcentral.com/articles/10.1186/ s12937-017-0303-0

24. Vianna MS, Silva PAB, Nascimento CV, Soares SM. Self-care competence in the administration of insulin in older people aged 70 or over. Rev LatinoAm Enfermagem [Internet]. 2017[cited 2019 Sep 09];25:e2943. Available from: https://www.scielo.br/pdf/rlae/v25/0104-1169-rlae-25-e2943.pdf

25. Pan A, Wang Y, Talaei M, Hu FB. Relation of smoking with total mortality and cardiovascular events among patients with diabetes mellitus: a meta-analysis and systematic review. Circulation [Internet]. 2015[cited 2019 Nov 11];132(19):1795-804. Available from: https://www. ahajournals.org/doi/10.1161/CIRCULATIONAHA.115.017926 
26. Joseph JJ, Tcheugui JBE, Carnethon MR, Bertoni AG, Shay CM, Ahmed HM, et al. The association of ideal cardiovascular health with incidente type 2 diabetes mellitus: the Multi-Ethnic Study of Atherosclerosis. Diabetologia [Internet]. 2016[cited 2019 Nov 11];59(9):1893-903. Available from: https://link.springer.com/article/10.1007\%2Fs00125-016-4003-7

27. Kar D, Gillies C, Nath M, Khunti K, Davies MJ, Seidu S. Association of smoking and cardiometabolic parameters with albuminuria in people with type 2 diabetes mellitus: a systematic review and meta-analysis. Acta Diabetol [Internet]. 2019[cited 2019 Dec 21];56(8):839-50. Available from: https://link.springer.com/article/10.1007\%2Fs00592-019-01293-x

28. Riviere M, Dufoort $H$, Van Hecke A, Vandecasteele T, Beeckman D, Verhaeghe S. Core elements of the interpersonal care relationship between nurses and older patients without cognitive impairment during their stay at the hospital: A mixed-methods systematic review. Int J Nurs Stud [Internet]. 2019[cited 2019 Dec 13];92:154-72. Available from: https://www.sciencedirect.com/science/article/abs/pii/ S0020748919300355?via\%3Dihub

29. Mulder BC, Van Belzen M, Lokhorst AM, Woerkum CMJ. Quality assessment of practice nurse communication with type 2 diabetes patients. Patient Educ Couns [Internet]. 2015[cited 2019 Nov 02];98(2):156-61. Available from: https://www.sciencedirect.com/science/article/abs/pii/ S0738399114004790?via\%3Dihub

30. Nogueira IS, Previato GF, Scolari GAS, Gomes ACO, Carreira L, Baldissera VDA. Home intervention as a tool for nursing care: evaluation of the satisfaction of the elderly. Rev Gaúcha Enferm [Internet]. 2016[cited 2019 Nov 08];37(esp):e68351. Available from: https://www.scielo.br/pdf/ rgenf/v37nspe/en_0102-6933-rgenf-1983-14472016esp68351.pdf

31. Araujo ESS, Silva LF, Moreira TMM, Almeida PC, Freitas MC, Guedes MVC. Nursing care to patients with diabetes based on King's Theory. Rev Bras Enferm [Internet]. 2018[cited 2019 Nov 29];71(3):1092-8. Available from: https://www.scielo.br/pdf/reben/v71n3/0034-7167-reben-71-03-1092.pdf

32. Whitehead LC, Crowe MT, Carter JD, Maskill VR, Carlyle D, Bugge C, et al. A nurse-led education and cognitive behaviour therapy-based intervention among adults with uncontrolled type 2 diabetes: a randomised controlled trial. J Eval Clin Pract [Internet]. 2017[cited 2019 Sep 11];23(4):821-9. Available from: https://onlinelibrary.wiley.com/doi/abs/10.1111/jep.12725

33. Trevisan DD, São-João T, Cornélio M, Jannuzzi F, Sousa MR, Rodrigues R, et al. Effect of an 'implementation intention' intervention on adherence to oral anti-diabetic medication in Brazilians with type 2 diabetes. Patient Educ Couns [Internet]. 2020[cited 2020 Feb 08];103(3):582-8. Available from: https://www.sciencedirect.com/science/article/abs/pii/S0738399119304392?via\%3Dihub

34. Ministério da Saúde (BR). Portaria n¹11/2016, de 28 de Janeiro de 2016 [Internet]. Dispõe sobre o Programa Farmácia Popular do Brasil (PFPB). Brasília: DF, 2016[cited 2019 Nov 11]. Available from: http://bvsms.saude.gov.br/bvs/saudelegis/gm/2016/prt0111_28_01_2016.html 